\title{
Pendred's syndrome - consequences of thyroidectomy
}

\author{
Christopher G. Winearls \\ D.Phil., M.R.C.P.
}

ROGER SMITH
M.D., F.R.C.P.

Department of Medicine, John Radcliffe Hospital II, Headington, Oxford

\begin{abstract}
Summary
A 73-year-old-man with Pendred's syndrome is described who presented with hypoparathyroidism and tracheal compression 31 years after thyroidectomy.
\end{abstract}

\section{Introduction}

The presence of a goitre in a patient with congenital perceptive deafness suggests the diagnosis of Pendred's syndrome. This disorder is well described (Pendred, 1896; Brain, 1927; Fraser, Morgans and Trotter, 1960) and has been reviewed by Fraser (1976) and Stanbury (1978) but it is sufficiently rare for the diagnosis to be delayed and the treatment to be inappropriate.

\section{Case report}

In February 1980 a euthyroid deaf man of 73 years was admitted with transient left-sided weakness after a grand mal convulsion. He had been deaf from birth. His speech was rudimentary and the remnant of the thyroid isthmus was enlarged. Stridor was audible and Trousseau's and Chvostek's signs were positive. Thirty-one years previously, a large goitre had been removed. Histological re-examination of this specimen revealed multiple microadenomata but no parathyroid tissue. In 1972 and 1973 his lenses had been removed for cataract.

The corrected plasma calcium was $0.95 \mathrm{mmol} / 1$, phosphate $2.04 \mathrm{mmol} / \mathrm{l}$, creatinine $95 \mu \mathrm{mol} / 1$ and alkaline phosphatase 245 i.u./l (normal 0-300). The QT interval on the ECG was abnormally long (480 msec; expected QT interval for the heart rate was 360 $\mathrm{msec})$. Radiography showed no intracranial calcification. The plasma thyroxine was $102 \mathrm{nmol} / \mathrm{l}$ (normal 70-140) and the TSH was $7 \mathrm{mu} . / 1$ (normal 0-6). Neither thyroid nor parathyroid autoantibodies were detected. Treatment with i.v. calcium (initially) and 1, $\alpha$-hydroxycholecalciferol 1-2 $\mu$ g daily reversed the biochemical abnormalities. He has had no further grand mal convulsions and the current (August 1980) plasma calcium is $2.36 \mathrm{mmol} / \mathrm{l}$ and phosphate $1.39 \mathrm{mmol} / \mathrm{l}$. A perchlorate discharge test was performed. Since perchlorate blocks the uptake of iodine in the thyroid, there is a rapid discharge of radioiodine after perchlorate administration to patients with iodine incorporation defects. The test was positive; $20 \mathrm{~min}$ after $643 \mu \mathrm{Ci}$ of i.v. ${ }^{123}$ I, the thyroid uptake was $4.1 \%$; he was then given $400 \mathrm{mg}$ of potassium perchlorate by mouth and after $20 \mathrm{~min}$ the uptake value was $1 \cdot 6 \%$. These figures are consistent with a diagnosis of Pendred's syndrome (Morgans and Trotter, 1958; Fraser et al., 1960). One of his sisters is congenitally deaf and has a large goitre which was first noted at puberty. She is clinically and biochemically euthyroid (T4 $=74$ $\mathrm{nmol} / \mathrm{l}$ and TSH $2 \mathrm{mu} . / \mathrm{l})$; she has no pressure symptoms from her goitre and her plasma calcium is normal. She declined a perchlorate discharge test. Another sister is not deaf and has no goitre. The parents were normal and not consanguinous.

During treatment, the hoarseness and stridor persisted. Direct laryngoscopy, tracheoscopy and upper oesophagoscopy performed under general anaesthetic were normal. There was no evidence of recurrent laryngeal palsy. Review of the chest radiograph showed that the trachea was deviated to the left in the superior mediastinum; tomograms showed extrinsic indentation of the trachea at or above the thoracic inlet by a mass on the right side. $A{ }^{99} \mathrm{Tc}$ scan of the region showed regrowth of the right side of the thyroid with a cystic area within it. The compression was not thought to be sufficient to warrant treatment.

\section{Discussion}

Pendred's syndrome consists of congenital sensorineural deafness and goitre due to an iodine-trapping defect. The diagnosis is worth making for 2 reasons. The first is that surgery, which may be unnecessary because the goitre can shrink after treatment with thyroxine (Thieme, 1957), is not without problems. The operation can be technically difficult because of the size of the gland, and is often followed by exuberant recurrence of the goitre. This recurrence may be mistaken for cancer so that further, more aggressive, surgery is attempted. Although Thieme 
(1957) and Elman (1958) have described patients with Pendred's syndrome in whom a histological diagnosis of carcinoma was made, Fraser (1976) doubts whether true malignancy has ever been documented and he attributes this diagnosis to the deceptive histological appearances. Surgery, particularly if it is repeated, may cause these patients to become hypothyroid (untreated, they are usually euthyroid). Moreover it would be reasonable to expect more frequent hypoparathyroidism after surgery for Pendred's syndrome than for other goitres, but neither the classic accounts of the disorder (Fraser, 1976) nor a recent review of hypoparathyroidism (Nagant de Deuxchaisnes and Krane, 1978) mention this possibility.

The second reason to diagnose the condition is the need for genetic counselling. Pendred's syndrome is an autosomal recessive (Brain, 1927; Fraser, Morgans and Trotter, 1960), and deaf people often marry one another; indeed the present patient had married a deaf mute but she has no goitre and they have no children.

It is assumed that the diagnosis of Pendred's syndrome was not made at the time of the patient's thyroidectomy and the indication for surgery is not known. This patient demonstrates 2 complications of surgery - hypoparathyroidism manifesting many years later as cataracts and tetany; and tracheal compression due to the typical regrowth of thyroid tissue seen in this condition.

\section{Acknowledgments}

Dr M. S. Dunnill, F.R.C.Path., performed the histological $\frac{\widehat{Q}}{\mathrm{Q}}$ examination of the thyroidectomy specimen. Mr N. Frootko, @ F.R.C.S., performed the otorhinolaryngological assessment $c$ and Dr D. Macey performed the perchlorate discharge test. $\overrightarrow{\vec{F}}$ The patient was referred by Dr Gordon Wilcock.

\section{References}

BRAIN, W.R. (1927) Heredity in simple goitre. Quarter'y Journal of Medicine, 20, 303.

ElmaN, D.S. (1958) Familial association of nerve deafness with nodular goitre and thyroid carcinoma. New England Journal of Medicine, 259, 219.

Fraser, G.R. (1976) Deafness with goitre (Pendred's $\overrightarrow{\vec{\omega}}$ syndrome). In: The Causes of Profound Deafness in Child-w hood, p. 11. Baillière Tindall, London.

Fraser, G.R., Morgans, M.E. \& Trotter, W.R. (1960) The syndrome of sporadic goitre and congenital deafness. Quarterly Journal of Medicine (New Series), 29, 279.

Morgans, M.E. \& Trotter, W.R. (1958) Association of $\sigma$ congenital deafness with goitre - the nature of the thyroid defect. Lancet, i, 607.

Nagant de Deuxchaisnes, C. \& Krane, S.M. (1978) Hypo- స్ parathyroidism. In: Metabolic Bone Disease, Vol. 2 (Eds Avioli, L.V. \& Krane, S.M.), p. 217. Academic Press, New York, San Francisco and London.

Pendred, V. (1896) Deaf-mutism and goitre. Lancet, ii, 532.

StanbuRY, J.B. (1978) Familial goitre. In: The Metabolic Basis of Inherited Disease (Ed by Stanbury, J.B., Wyд- $\overrightarrow{0}$ gaarden, J.B. \& Fredrickson, D.S.), 4th edn, p. $22 . \infty$ McGraw-Hill, U.S.A.

ThIEME, E.T. (1957) A report of the occurrence of defimutism and goitre in four of six siblings of a Nor American family. Annals of Surgery, 146, 941. 